九州大学学術情報リポジトリ

Kyushu University Institutional Repository

\title{
Composition and Cementation of Some Lower Palaeozoic Grits in Wales
}

Okada, Hakuyu

Faculty of Science, Kyushu University

https://doi.org/10.5109/1543656

出版情報：九州大學理學部紀要：Series D, Geology. 18 (2)，pp. 261-276，1967-12-25. Faculty of Science, Kyushu University バージョン:

権利関係: 
Mem. Fac. Sci., Kyushu Univ., Ser. D, Geology, Vol. XVIII, No. 2, pp. 261-276, text-figs. 1-5, tables 1-2, pl. 2, Dec. 25,1967

\title{
Composition and Cementation of Some Lower Palaeozoic Grits in Wales
}

\author{
By
}

Hakuyu OKADA

\begin{abstract}
Composition and mode of cementation of some Cambro-Silurian grits in Wales are reported. The Cambrian grits are characterised by granitic and gneissic clasts; the Upper Llandovery by rhyolitic and porphyritic fragments; the Wenlock (Denbigh) grits by more basic volcanic materials. Nevertheless, there is no significant difference in the composition of clay cements, especially chloritic minerals. Clay cements of secondary origin play a minor role. GILBERT's classificatory scheme (1954) is, with some modification, reasonably applicable to the grits.
\end{abstract}

\section{Introduction}

The author has investigated some Lower Palaeozoic grits in Wales in the hope of clarifying the significance of "greywacke" in geosynclines, especially the occurrence of greywacke and the origin of its matrix. This has shed further light on the greywacke problem in turbidite successions, and underlines the importance of the occurrence of non-greywacke sandstones in the "greywacke suite" (OKADA, 1966).

In the present paper sandstones from some selected sequences of the Welsh Cambrian and Silurian have been examined as regards compositional features and their relation to the mode of cementation. An account is given of sandstone nomenclature.

\section{Petrological samples}

The petrological samples described include all the materials referred to in a previous paper (OKADA, 1966) and 28 supplementary ones. They were collected from the Dolwen Grits, Rhinog Grits, Barmouth Grits, Gamlan Grits and Flags, Vigra Flags, and Ffestiniog Flags (in ascending order) of the Lower and Middle Cambrian in the Harlech Dome (MATLEY and Wilson, 1946); from the Upper Llandovery (Lower Silurian) Aberystwyth Grits (Wood and SMITH, 1959) and their equivalents in South Wales; and from the Wenlock (Middle Silurian) Denbigh Grits (Cummins, 1957) in North Wales (Fig.1). More detailed information of the sampled positions is listed in Table 1.

Manuscript received August 3, 1967. 


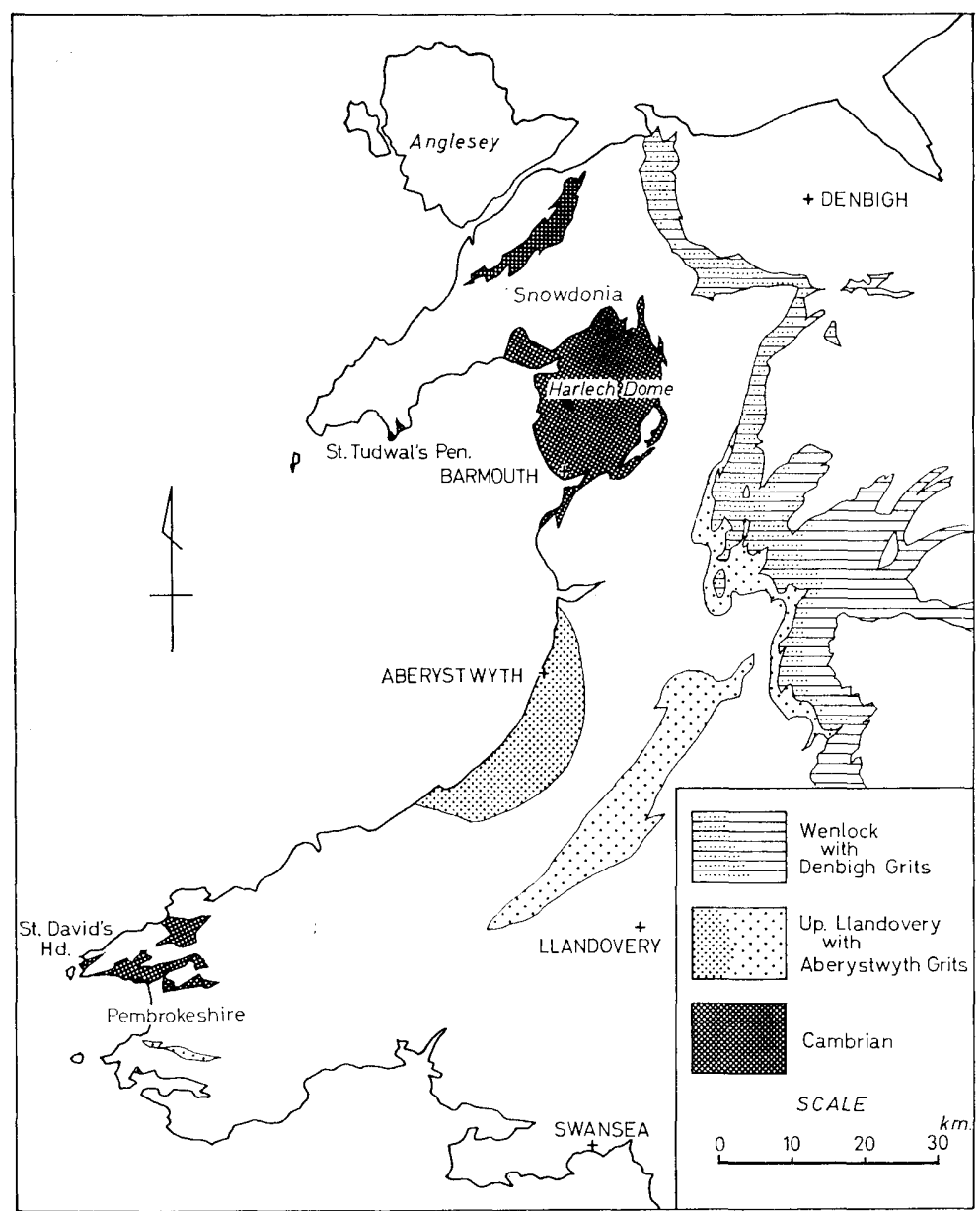

Fig. 1. Index map of the studied area showing the distributions of Cambrian, Upper Llandovery and Wenlock grits.

The petrological procedures adopted (using this sections) have been described (OKADA, 1966). Heavy mineral analyses were carried out in Thoulet's liquid (s.gr.=2.9) (OKADA, 1960). In addition, X-ray analysis was applied to the matrix in the sandstones (separated by an ultrasonic clearner and gravitational sedimentation) and to certain shales and flags for comparison.

\section{Composition of the Cambrian grits}

The composition of the Cambrian grits and flags in the Harlech Dome has been reported by WoodLAND $(1938,1939,1946)$ and others (e.g. BASSETT and WALTON, 1960). Their work has now been extended on a quantitative basis.

Modal analyses (Swift point-counter: $1000-1500$ points over $300-400 \mathrm{~mm}^{2}$ ) have been made of twenty-one thin sections of sandstones from the Dolwen, Rhinog, Manganese, Barmouth and Gamlan Grits (Table 1). 
Quartz. Quartz is the dominant detrital mineral in all the grits. Polycrystalline quartz usually predominates over monocrystalline. Grains of both bear minute opaque inclusions and gas- or liquid-bubbles. Vermicular-chlorite-bearing quartz (cf. Pl. 2, Fig. 2 with WALLIS, 1927, pl. LVIII) occurs rarely. Many grains show various grades of strain shadows. Occasional ones present intense undulose extinction, the direction of which is parallel to the alignment of fibrous chlorite and sericite which, in turn, is at right angles to the stress.

Conspicuous rounding of some grains, rather independent of grain size, is characteristic of all the Cambrian grits (see Roundness in Table 1). It suggests derivation from Precambrian sediments, as proposed by WoodLAND (1947, p. 34) and BASSET and WALTON (1960, p. 95).

Feldspars. Feldspars, including both alkali-feldspars and plagioclase, are subordinate. The alkali-feldspars, consistently the commoner of the two, comprise orthoclase, perthite, microcline and myrmekite. Orthoclase always outnumbers the others. Perthitic alkali-feldspar is frequent in the Barmouth Grits and Gamlan Grits. Myrmekite is not, but traces persist throughout the grits. Microcline was recognised only in the Gamlan Grits. Plagioclase fragments with albite-twin lamellae are quite common (extinction angles $9^{\circ}-17^{\circ}$, rarely $21^{\circ}$ ). Most are thought to be oligoclase; some andesine. Albite-carlsbad twinning is common. Partial decomposition to a kaolin-like mineral and sericite features all the feldspar grains. Epidote sometimes develops at their edges, particularly in the Dolwen Grits.

Rock fragments. Rock fragments recognised are granite, graphic granite, granophyre, porphyritic rocks, rhyolite, andesitic rocks and fine-grained quartzose sandstone. The granitic types are by far the commonest. Further information is given by WoodLAND (1947), who examined the pebbles in grits in detail.

Argillaceous matrix. The amount of the 'clay' matrix increases with decreasing grain-size. Coarse-grained sandstones usually contain less than 15 percent. The matrices consist of chlorite, sericite and secondary quartz. Chlorite and sericite occur as parallel fibres or lath-shaped crystals, either lined up with the bedding or set at right angles to the stress. Detrital grains usually show fretted edges due to marginal corrosion, supporting perpendicularly arranged chlorite laths or fibres. This phenomenon is particularly distinct at edges free from dynamic stress (PI. 2, Fig. 1).

The chlorite shows various shades of green, with slight to fairly distinct pleochroism. Many of the laths or fibres have positive elongation. According to HEY's classification (1954), the chlorite falls in the fields of thuringite or pseudothuringite to ripidolite (Fig. 2). Woobland (1938, pp. 375-376) has reported an $\mathrm{Fe}_{2} \mathrm{O}_{3}$-deficient chlorite $\left(\mathrm{Fe}_{2} \mathrm{O}_{3}\right.$ as low as 0.58 percent) from a carbonate rock in the Manganese Shale Group.

Accessary heavy minerals. Separated heavy mineral grains comprise the following translucent minerals, in order of general abundance: zircon, tourmaline, garnet, epidote, augite, anatase and rutile (Table 2, sp. nos. W 13-26C). Opaque minerals in order of abundance are: pyrite, leucoxene or ilmenite, and magnetite.

Zircon is the commonest mineral except in the Dolwen Grit samples. It ex- 


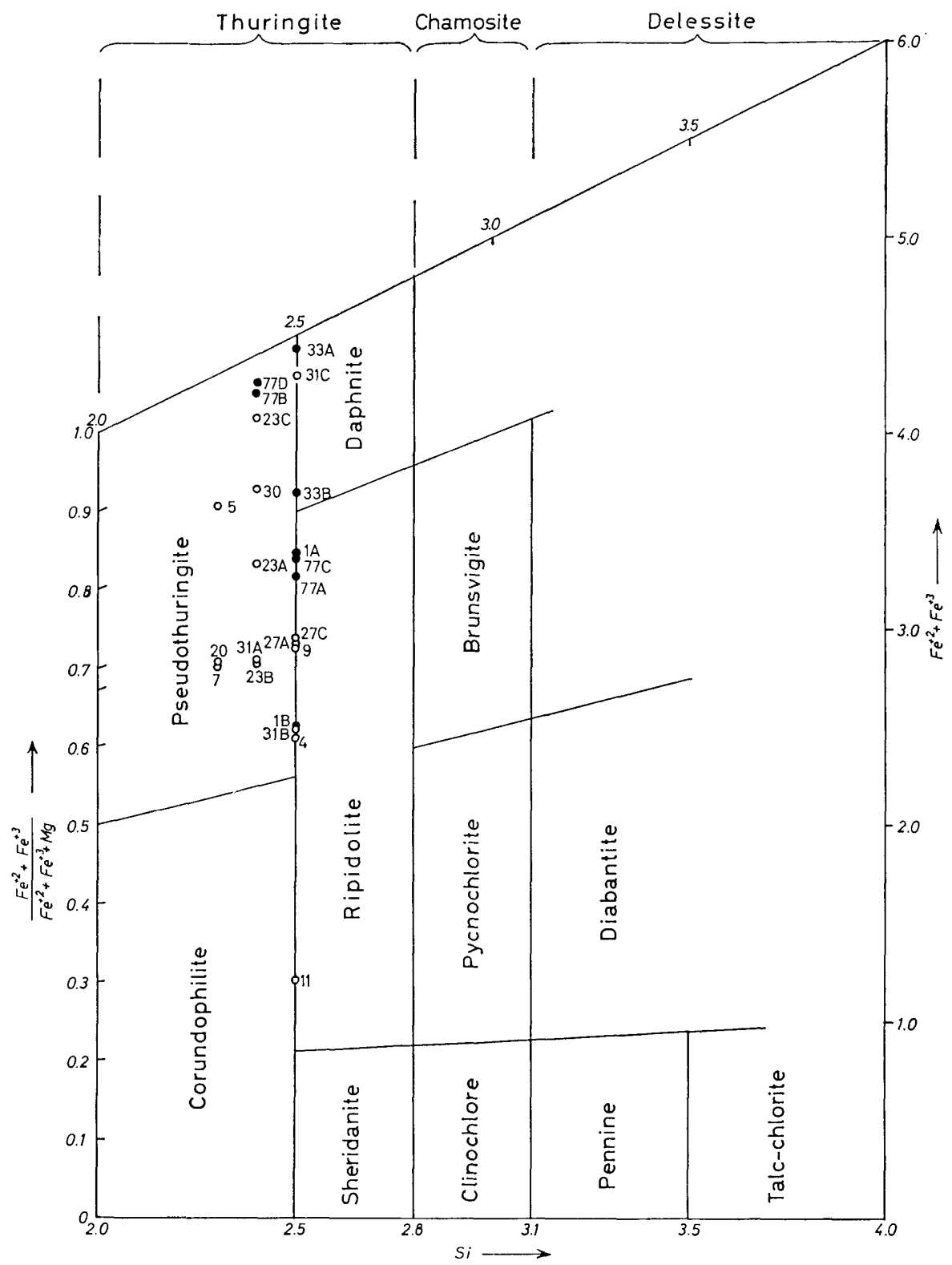

Fig. 2. Chlorite composition after HEY (1954), determined by X-ray powder diagrams.

Cambrian-open circles:

$\begin{array}{rll}4 & \text { SH 564373 } & \text { Ffestiniog Flags } \\ 5 & \text { Do. } & \text { Do. } \\ 7 & \text { SH 523374 } & \text { Mantwrog Flags } \\ 9 & \text { Do. } & \text { Do. } \\ 11 & \text { SH 701304 } & \text { Dolwen Grits } \\ 23 A & \text { SH 618155 } & \text { Gamlan Grits }\end{array}$


Table 1. Modal analysis of sandstones(1).

\begin{tabular}{|c|c|c|c|c|c|c|c|c|c|c|c|c|c|c|c|c|c|c|c|c|c|c|c|}
\hline \multirow[b]{2}{*}{ 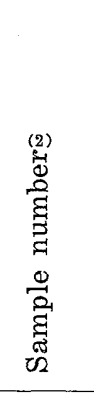 } & \multirow[b]{2}{*}{ 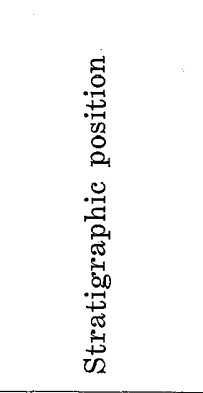 } & \multirow{2}{*}{ 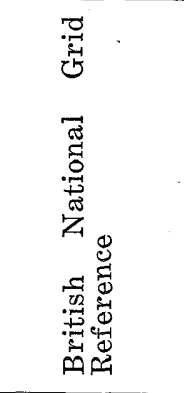 } & \multirow[b]{2}{*}{ 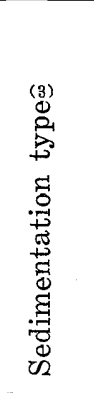 } & \multirow{2}{*}{ 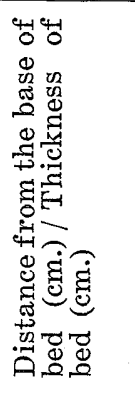 } & \multicolumn{2}{|c|}{ Quartz } & \multicolumn{2}{|c|}{$\begin{array}{l}\text { Feld- } \\
\text { spar }\end{array}$} & & & Cems & & & & & & & & undne & $\operatorname{ess}^{(4)}$ & & & \\
\hline & & & & & 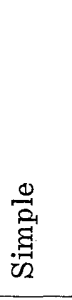 & 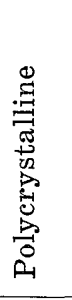 & 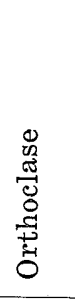 & 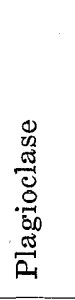 &  & 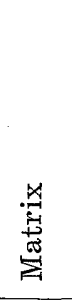 & 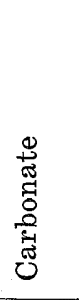 & 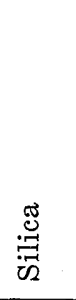 & 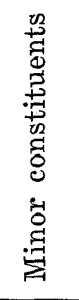 & 胥 & 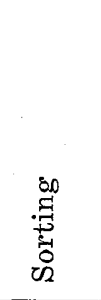 & 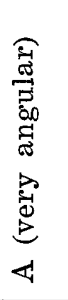 & 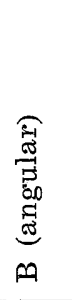 & 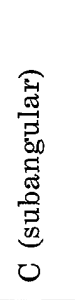 & 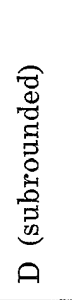 & 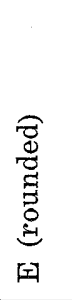 & 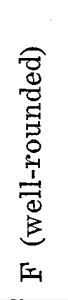 & 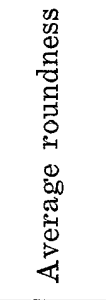 & 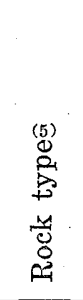 \\
\hline 12 & Dolwe & SH 689303 & & & 5 & 70 & 14 & - & 8 & 2 & 1 & & - & -0.15 & 1.19 & 2 & 17 & 45 & 31 & 5 & 0 & $\begin{array}{c}\mathrm{C} \\
0.33 \\
\mathrm{~B}\end{array}$ & $\mathrm{FA}$ \\
\hline 13 & Grits & SH 689303 & & & 11 & 35 & 9 & 7 & 2 & 35 & & & 1 & 2.51 & 0.54 & 8 & 56 & 34 & 2 & 0 & 0 & $\begin{array}{c}\mathrm{B} \\
0.24\end{array}$ & $\mathrm{FW}$ \\
\hline 14 & Rhinog: & SH 677240 & $\mathrm{Ta}$ & $1 / 30$ & 22 & 34 & 7 & 3 & 9 & 24 & - & & - & 1.95 & 0.95 & 1 & 17 & 41 & 33 & 6 & 2 & $\begin{array}{c}\mathrm{D} \\
0.40 \\
\mathrm{C}\end{array}$ & $\mathrm{FW}$ \\
\hline $31 \mathrm{~A}$ & Grits & SH 613161 & $\mathrm{Ta}$ & $2 / 50$ & 28 & 24 & 7 & 1 & 7 & 34 & - & & - & 2.20 & 0.89 & 1 & 26 & 46 & 24 & 3 & 0 & 0.31 & $\mathrm{FW}$ \\
\hline $31 \mathrm{~B}$ & & $\mathrm{SH} 613161$ & $\mathrm{~Tb}$ & $30 / 50$ & 13 & 38 & 10 & 3 & 2 & 31 & 3 & & - & 1.95 & 0.90 & 11 & 42 & 37 & 9 & 1 & 0 & $\begin{array}{l}\mathrm{C} \\
0.26\end{array}$ & $\mathrm{FW}$ \\
\hline $31 \mathrm{C}$ & & SH 613161 & $\mathrm{Te}$ & $40 / 50$ & 6 & 2 & 3 & 2 & 1 & 83 & & & 3 & & & & & & & & & & \\
\hline 30 & $\begin{array}{c}\text { Manganese } \\
\text { Group }\end{array}$ & SH 613159 & $\mathrm{Ta}$ & $10 / 40$ & 15 & 24 & 2 & - & 2 & 55 & 1 & & 1 & 2.50 & 1.28 & 4 & 31 & 42 & 20 & 2 & 1 & $\begin{array}{c}\mathrm{C} \\
0.30\end{array}$ & $\mathrm{QW}$ \\
\hline $27 \mathrm{~A}$ & & SH 617156 & $\mathrm{Ta}$ & $3 / 38$ & 33 & 30 & 7 & 5 & 5 & 18 & 2 & & - & 0.25 & 1.67 & 1 & 16 & 37 & 44 & 2 & - & $\begin{array}{c}\mathrm{C} \\
0.34 \\
\mathrm{Bi}\end{array}$ & $\mathrm{FW}$ \\
\hline $27 \mathrm{~B}$ & & SH 617156 & $\mathrm{~Tb}$ & $30 / 38$ & 21 & 20 & 7 & 5 & 2 & 44 & - & & 1 & 2.75 & 0.75 & 27 & 53 & 17 & 3 & 0 & 0 & 0.21 & FW \\
\hline $27 \mathrm{C}$ & Barmouth & SH 617156 & $\mathrm{Tc}$ & $.35 / 38$ & 6 & 1 & & - & - & 91 & & & 2 & & & & & & & & & $\mathrm{C}$ & \\
\hline $28 \mathrm{~A}$ & Grits & SH 617156 & $\mathrm{Ta}$ & $4 / 80$ & 24 & 34 & 15 & 4 & 8 & 5 & 10 & & - & 0.80 & 1.53 & 5 & 25 & 43 & 27 & - & 0 & 0.30 & $\mathrm{FA}$ \\
\hline $28 \mathrm{~B}$ & & SH 617156 & $\mathrm{~Tb}$ & $70 / 80$ & 18 & 32 & 9 & 2 & 2 & 37 & - & & - & 2.35 & 0.83 & 11 & 44 & 35 & 9 & 1 & 0 & 0.26 & FW \\
\hline $29 \mathrm{~A}$ & & SH 617156 & $\mathrm{Ta}$ & $5 / 70$ & 21 & 48 & 9 & 5 & 1 & 15 & 1 & & - & 2.15 & 0.99 & 21 & 52 & 18 & 7 & 2 & 0 & 0.23 & $\mathrm{FW}$ \\
\hline $29 \mathrm{~B}$ & & SH 617156 & $\mathrm{~Tb}$ & $50 / 70$ & 17 & 26 & 10 & 2 & 1 & 44 & - & & - & 2.60 & 0.90 & 4 & 51 & 36 & 9 & - & 0 & 0.26 & $\mathrm{FW}$ \\
\hline 16 & & SH 618155 & $\mathrm{Ta}$ & $3 / 45$ & 39 & 30 & 12 & 1 & 3 & 14 & - & & - & 0 & 1.13 & - & 15 & 42 & 35 & 7 & - & $\begin{array}{c}\mathrm{C} \\
0.34 \\
\mathrm{D}\end{array}$ & FA \\
\hline $23 \mathrm{~A}$ & Gamlan & SH 618155 & $\mathrm{Ta}$ & $2 / 30$ & 20 & 38 & 17 & 1 & 2 & 19 & 3 & & - & 0.05 & 1.52 & 1 & 10 & 31 & 56 & 2 & 0 & 0.36 & $\mathrm{FW}$ \\
\hline 24 & S rita & SH 618155 & $\mathrm{Ta}$ & $2 / 40$ & 10 & 39 & 10 & 1 & - & 34 & 6 & & - & 2.22 & 0.57 & 3 & 44 & 39 & 13 & 1. & 0 & 0.27 & $\mathrm{FW}$ \\
\hline $26 \mathrm{~A}$ & & SH 618155 & $\mathrm{Ta}$ & $5 / 50$ & 40 & 21 & 13 & 1 & - & 9 & 8 & & - & 0.47 & 1.02 & 12 & 38 & 44 & 6 & - & 0 & 0.25 & $\mathrm{FA}$ \\
\hline $26 \mathrm{~B}$ & & $\mathrm{SH} 618155$ & $\mathrm{Ta}$ & $30 / 50$ & 9 & 45 & 9 & 3 & 1 & 27 & 6 & & - & 2.05 & 0.75 & 9 & 36 & 43 & 11 & 1 & 0 & 0.27 & $\mathrm{FW}$ \\
\hline $26 \mathrm{C}$ & & SH 618155 & $\mathrm{~Tb}$ & $40 / 50$ & 2 & 37 & 4 & 1 & - & 55 & 1 & & - & 3.03 & 0.60 & & & & & & & & $\mathrm{QW}$ \\
\hline 66 & & SN 384603 & $\mathrm{Ta}$ & $2 / 5$ & 11 & 24 & 11 & 3 & 6 & 41 & 3 & & 1 & 3.07 & 1.10 & - & 5 & 56 & 19 & - & 0 & $\begin{array}{c}\mathrm{C} \\
0.30\end{array}$ & $\mathrm{FW}$ \\
\hline 67 & vyth & SN 384603 & $\mathrm{Ta}$ & $3 / 50$ & 20 & 23 & 13 & 2 & 6 & 32 & 3 & & 1 & 2.80 & 0.85 & - & 19 & 55 & 24 & 2 & 0 & 0.32 & $\mathrm{FW}$ \\
\hline $69 \mathrm{~A}$ & Grits & SN 384603 & $\mathrm{Ta}$ & $0.5 / 22$ & 23 & 11 & 16 & 1 & 26 & 2 & 21 & & $T$ & 0.70 & 1.75 & 9 & 32 & 46 & 12 & 1 & 0 & 0.27 & LA \\
\hline $69 \mathrm{~B}$ & & SN 384603 & $\mathrm{Ta}$ & $5 / 22$ & 26 & 13 & 16 & 3 & 11 & 16 & 14 & & 1 & 2.05 & 1.20 & 4 & 16 & 57 & 22 & 1 & 0 & 0.31 & FW \\
\hline $69 \mathrm{C}$ & & SN 384603 & $\mathrm{Ta}$ & $10 / 22$ & 24 & 23 & 16 & 2 & 6 & 22 & 6 & & 1 & 2.05 & 0.99 & 3 & 33 & 38 & 24 & 2 & 0 & 0.30 & $\mathrm{FW}$ \\
\hline $69 \mathrm{D}$ & & $\mathrm{SN} \cdot 384603$ & $\mathrm{Ta}$ & $14 / 22$ & 26 & 18 & 5 & 2 & 14 & 21 & 9 & & - & 2.10 & 0.98 & - & 23 & 58 & 19 & 0 & 0 & 0.30 & LW \\
\hline $69 \mathrm{E}$ & & SN 384603 & $\mathrm{~Tb}$ & $18 / 22$ & 21 & 16 & 14 & 2 & 10 & 23 & 11 & & - & 1.90 & 1.05 & 2 & 39 & 55 & 4 & 0 & 0 & 0.27 & $\mathrm{FW}$ \\
\hline $69 \mathrm{~F}$ & & SN 384603 & $\mathrm{~Tb}$ & $21 / 22$ & 19 & 18 & 11 & 1 & 6 & 35 & 9 & & 1 & 2.30 & 0.90 & 1 & 23 & 66 & 10 & 0 & 0 & 0.31 & $\mathrm{FW}$ \\
\hline $70 \mathrm{~A}$ & & SN 386605 & $\mathrm{Ta}$ & $95 / 100$ & 28 & 9 & 10 & 2 & 15 & 32 & 3 & & - & 2.65 & 0.85 & 6 & 26 & 57 & 11 & 0 & 0 & $\underset{\mathrm{C}}{0.28}$ & $\mathrm{LW}$ \\
\hline $70 \mathrm{~B}$ & & SN 386605 & dyke & & 24 & 23 & 6 & 2 & 13 & 12 & 19 & & - & 2.70 & 0.65 & 9 & 43 & 44 & 4 & - & 0 & 0.25 & LA \\
\hline 71 & & SN 386605 & $\mathrm{Ta}$ & $1 / 15$ & 23 & 14 & 15 & 1 & 10 & 27 & 4 & & - & 1.30 & 1.03 & 0 & 14 & 68 & 18 & - & 0 & 0.31 & $\mathrm{FW}$ \\
\hline 75 & & SN 490649 & $\mathrm{Ta}$ & $1 / 25$ & 19 & 18 & 8 & 1 & 12 & 27 & 14 & & 1 & 2.55 & 1.09 & 0 & 10 & 62 & 28 & - & 0 & $\stackrel{0.32}{\mathrm{C}}$ & $L W$ \\
\hline $77 \mathrm{~A}$ & & SN 490649 & $\mathrm{Ta}$ & $1 / 45$ & 11 & 16 & 6 & - & 44 & 11 & 12 & & - & 2.65 & 1.89 & 0 & 16 & 50 & 34 & - & 0 & $\begin{array}{c}0.33 \\
\mathrm{D}\end{array}$ & LA \\
\hline $77 \mathrm{~B}$ & & SN 490649 & $\mathrm{Ta}$ & $30 / 45$ & 22 & 17 & 7 & - & 8 & 34 & 11 & & 1 & 3.05 & 1.00 & 1 & 27 & 60 & 12 & - & 0 & 0.39 & $\mathrm{LW}$ \\
\hline $77 \mathrm{C}$ & & $\mathrm{SN} 490649$ & $\mathrm{~Tb}$ & $40 / 45$ & 2 & 31 & 4 & 1 & 1 & 48 & 11 & & 2 & 4.05 & 0.70 & & & & & & & & $\mathrm{FW}$ \\
\hline $78 \mathrm{~A}$ & & SN 490649 & $\mathrm{~Tb}$ & $20 / 200$ & 16 & 25 & 9 & 1 & 12 & 22 & 12 & & 3 & 2.72 & 1.01 & 1 & 24 & 59 & 16 & 0 & 0 & 0.29 & $\mathrm{LW}$ \\
\hline $78 \mathrm{~B}$ & & SN 490649 & $\mathrm{Tc}$ & $170 / 200$ & 22 & 15 & 13 & 1 & 21 & 10 & 18 & & - & 0.85 & 0.95 & 3 & 17 & 50 & 27 & 3 & 0 & 0.32 & $\mathrm{LA}$ \\
\hline $78 \mathrm{C}$ & & SN 490649 & $\mathrm{~Tb}$ & $145 / 150$ & 24 & 25 & 8 & 2 & 9 & 29 & 3 & & - & 2.43 & 0.92 & 5 & 29 & 51 & 15 & 0 & 0 & 0.28 & $\mathrm{FW}$ \\
\hline 83 & & SN 555745 & $\mathrm{Ta}$ & $3 / 20$ & 35 & 26 & 3 & - & 7 & 25 & 4 & & - & 3.10 & 0.53 & 8 & 19 & 58 & 15 & - & 0 & 0.29 & $\mathrm{QW}$ \\
\hline $88 \mathrm{~A}$ & & SN 385604 & $\mathrm{Ta}$ & $2 / 5$ & 33 & 13 & 9 & 3 & 20 & 5 & 19 & & - & 1.10 & 1.23 & 10 & 35 & 32 & 22 & 1 & 0 & $\underset{\mathrm{B}}{0.28}$ & LA \\
\hline $88 \mathrm{~B}$ & & SN 385604 & $\mathrm{Ta}$ & $4 / 5$ & 32 & 11 & 6 & 3 & 5 & 34 & 7 & & 1 & 2.30 & 0.93 & 28 & 39 & 26 & 7 & 0 & 0 & 0.23 & $\mathrm{FW}$ \\
\hline 84 & & SM 784074 & & $50 / 100$ & 8 & & 1 & 5 & - & & & 9 & - & & & & & & & & & & $\mathrm{QA}$ \\
\hline 87 & & SM 932091 & & $5 / 30$ & 11 & 13 & - & - & 64 & 7 & - & 4 & - & 0.70 & 1.03 & 1 & 16 & 48 & 31 & 4 & 0 & $\begin{array}{l}\mathrm{C} \\
0.33\end{array}$ & LA \\
\hline 89 & & SN 656483 & & & 18 & 17 & 3 & 3 & 18 & 26 & 15 & & - & 2.10 & 1.25 & 14 & 39 & 34 & 11 & 2 & - & 0.27 & $L W$ \\
\hline 90 & Up. L & SN 701681 & $\mathrm{~Tb}$ & $1 / 4$ & 53 & 15 & 1 & - & 10 & & 22 & & - & 1.18 & 0.50 & 12 & 29 & 45 & 11 & 3 & 0 & 0.28 & $\mathrm{QA}$ \\
\hline $91 \mathrm{~A}$ & rits & SH 895122 & $\mathrm{Ta}$ & $2 / 30$ & 19 & 7 & 5 & 2 & 45 & 14 & 7 & & - & 0.87 & 0.81 & 9 & 41 & 34 & 14 & 2 & - & 0.27 & LA \\
\hline $91 \mathrm{~B}$ & & SH 895122 & $\mathrm{Ta}$ & $10 / 30$ & 23 & 10 & 3 & 1 & 29 & 29 & 4 & & 1 & 1.52 & 0.10 & 8 & 40 & 39 & 12 & 1 & 0 & 0.27 & $L W$ \\
\hline $91 \mathrm{C}$ & & SH 895122 & $\mathrm{Ta}$ & $25 / 30$ & 14 & 25 & 1 & 1 & 4 & 46 & 7 & & 2 & 3.50 & 0.70 & & & & & & & & $\mathrm{LW}$ \\
\hline $102 \mathrm{~A}$ & & SO 052552 & & $1 / 15$ & 41 & 31 & & & 6 & 8 & & 12 & 2 & 0 & 1.60 & 0 & 0 & 9 & 36 & 32 & 23 & 0.56 & $\mathrm{QA}$ \\
\hline $102 \mathrm{~B}$ & & So 052552 & & $13 / 15$ & 46 & 20 & & - & 7 & 13 & - & 7 & 8 & 1.05 & 1.28 & 0 & 8 & 19 & 26 & 30 & 17 & 0.50 & $\mathrm{QA}$ \\
\hline $1 \mathrm{~A}$ & & SH 992121 & $\mathrm{Ta}$ & $2 / 60$ & 16 & 21 & 8 & 4 & 34 & 10 & 6 & & 1 & 1.82 & 1.08 & 10 & 42 & 37 & 9 & 2 & 0 & $\begin{array}{c}\mathrm{C} \\
0.27\end{array}$ & LA \\
\hline $1 \mathrm{~B}$ & & SH 992121 & $\mathrm{~Tb}$ & $50 / 60$ & 20 & 27 & 5 & 1 & 13 & 30 & 4 & & - & 2.50 & 0.75 & 20 & 40 & 35 & 5 & - & 0 & $\begin{array}{c}\mathrm{C} \\
0.26\end{array}$ & $\mathrm{LW}$ \\
\hline 2 & & SH 992121 & $\mathrm{Ta}$ & $2 / 30$ & 13 & 20 & 4 & 3 & 20 & 37 & - & & 3 & 2.45 & 1.00 & 22 & 42 & 34 & 2 & - & 0 & $\begin{array}{l}\mathrm{D} \\
0.23 \\
\mathrm{C}\end{array}$ & $\mathrm{LW}$ \\
\hline $3 \mathrm{~A}$ & Gr & SH 992121 & $\mathrm{Ta}$ & $3 / 50$ & 19 & 18 & 10 & 3 & 26 & 9 & 16 & & - & 1.65 & 1.08 & 14 & 39 & 33 & 12 & 2 & 0 & 0.26 & $\mathrm{LA}$ \\
\hline $3 \mathrm{~B}$ & & SH 992121 & $\mathrm{Ta}$ & $40 / 50$ & 22 & 14 & 4 & 2 & 17 & 37 & 4 & & - & 2.30 & 1.10 & 15 & 43 & 30 & 12 & 0 & 0 & $\begin{array}{l}\mathrm{C} \\
0.25\end{array}$ & $\mathrm{LW}$ \\
\hline $33 \mathrm{~A}$ & & SJ 064484 & $\mathrm{Ta}$ & $2 / 50$ & 16 & 29 & 2 & 1 & 6 & 44 & 1 & & 1 & 2.45 & 1.30 & 9 & 30 & 42 & 20 & 1 & 0 & $\begin{array}{l}\mathrm{C} \\
0.29\end{array}$ & $\mathrm{LW}$ \\
\hline $34 \mathrm{~A}$ & & SJ 064484 & $\mathrm{Ta}$ & $3 / 36$ & 32 & 34 & 7 & 2 & 12 & 11 & 2 & & - & 1.43 & 0.66 & 15 & 38 & 43 & 4 & 0 & 0 & 0.25 & LA \\
\hline $34 \mathrm{~B}$ & & SJ 064484 & $\mathrm{~Tb}$ & $30 / 36$ & 10 & 47 & 2 & 2 & 3 & 35 & 1 & & - & 3.00 & 0.73 & 26 & 34 & 38 & 2 & 0 & 0 & 0.23 & $\mathrm{QW}$ \\
\hline
\end{tabular}

(1) Additional data to OKADA (1966).

2) Prefix $\mathrm{W}$ is omitted from all the sample numbers. Hand specimens and thin-sections used in this study are preserved in the Type Specimen Room, Department of Geology, Kyushu University, Fukuoka, Japan.

(3) BoUMA's scheme (1962).
(4) B: angular, C: subangular, D: subrounded, E: rounded.
(5) FA: feldspathic arenite, LA: lithic arenite, QA : quartz arenite, FW: Feldspathic wacke, LW: lithic wacke, QW : quartz wacke. 
ceeds 60 percent in the non-opaque suite. Most grains are euhedral and colourless to pale-pink. Well-rounded purple zircon is not uncommon. Twinned crystals and overgrowths on prisms were also seen.

Tourmaline grains, including brown, brownish green and green varieties, are fairly common. Grains of all these varieties are usually euhedral or subhedral prisms with rhombohedral terminations or basal partings. Some show an elongation ratio as much as 5. Opaque inclusions are common. Colour banding of the prismatic grains, running parallel to the basal plane, is commonly encountered, rendering them brown to reddish brown at one end and green at the other. Overgrowths at one end have been noted. Secondary overgrowths have usually been reported on well-rounded tourmaline nuclei (DÉvERIN, 1934; KRYNINE, 1946; and others). Provenance of detrital tourmalines may include KRYNINE's granitic and metamorphic terrains. Rounded tourmaline is occasionally found, derived from older sediments. In addition, WoodLAND (1938, pp. 377378) regarded a certain tourmaline in the mudstones as authigenic, and attributed the ultimate source to quartz veins traversing the rocks.

Garnet is fairly common. It occurs as angular conchoidally fractured grains of irregular form; sometimes as abraded dodecahedra. According to Wooduand (1938, pp. 367, 376-377), colourless garnet in the mudstones of the Manganese Group was formed secondarily by the interaction of chlorite and sericite with manganese carbonate and silicą.

Yellowish green epidote is abundant in the Dolwen Grits and extremely rare in the younger formations. Some of the epidotes are thought to be alteration products of feldspars.

Augite is very rare. It is pale greenish, prismatic and faintly cleaved. In specimen $\mathrm{W} 27 \mathrm{~B}$, there is a grain $0.5 \mathrm{~mm}$ long.

- Anatase is also very rare. A yellow variety occurs in the Gamlan Grits as rectangular grains with (001) cleavage. The surfaces of some grains are obliquely striated. Relict ilmenite and/or leucoxene, from which the anatase may have been produced, is often recognizable at the edges of the anatase crystals.

$\begin{array}{rlll}\text { 23B } & \text { Do. } & \text { Do. } & \text { (do.) } \\ \text { 23C } & \text { Do. } & \text { Do. } & \text { (shale) } \\ \text { 27A } & \text { SH } 617156 & \text { Barmouth Grits } & \text { (feldspathic wacke) } \\ \text { 27B } & \text { Do. } & \text { Do. } & \text { (do.) } \\ \text { 31A } & \text { SH } 613159 & \text { Rhinog Grits } & \text { (feldspathic wacke) } \\ \text { 31B } & \text { Do. } & \text { Do. } & \text { (do.) } \\ \text { 31C Do. } & \text { Do. } & \text { (shale) } \\ \text { ilurian-black dots: } & & \\ \text { 1A SH } 992121 & \text { Denbigh Grits } & \text { (lithic arenite) } \\ \text { 1B } & \text { Do. } & \text { Do. } & \text { (lithic wacke) } \\ \text { 33A SJ } 064484 & \text { Do. } & \text { (do.) } \\ \text { 33B } & \text { Do. } & \text { Do. } & \text { (shale) } \\ \text { 77A SN } 490649 & \text { Aberystwyth Grits } & \text { (lithic arenite) } \\ \text { 77B } & \text { Do. } & \text { Do. } & \text { (lithic wacke) } \\ \text { 77C Do. } & \text { Do. } & \text { (do.) } \\ \text { 77D } & \text { Do. } & \text { Do. } & \text { (shale) } \\ & & & \end{array}$


Table 2. Association of heavy minerals of some selected sandstones.

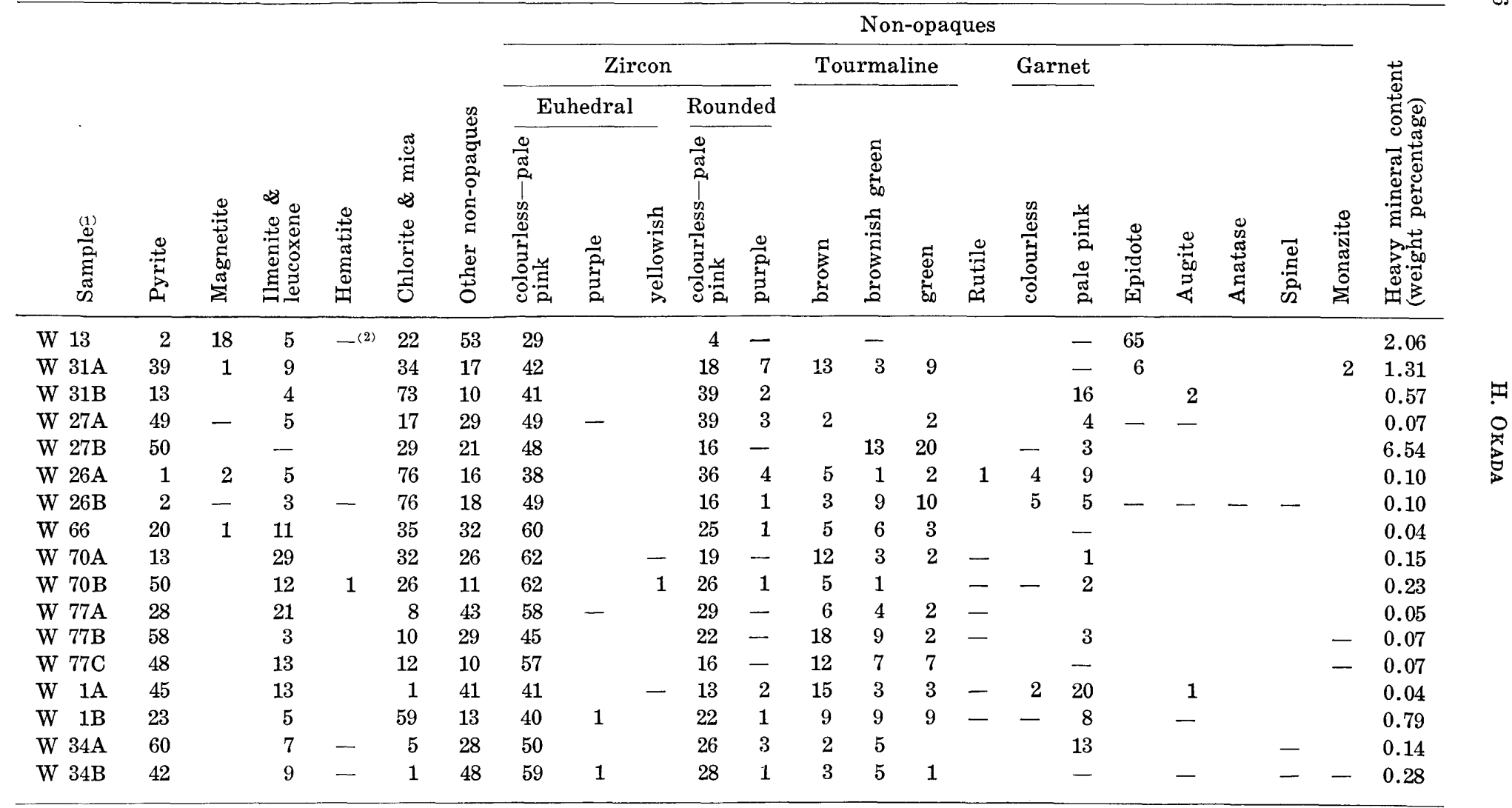

(1) W 13: Dolwen Grits, W 31A, B: Rhinog Grist, W 27A, B: Barmouth Grits, W 26A, B: Gamlan Grits, W 66-77: Aberystwyth Grits, W 1-34: Denbigh Grits.

(2) - : a traceable amount. 
The bluish variety was not detected, although reported by WoodLAND (1938) from the Bluestone Grits or Lower Shales of the Manganese Group.

Spinel occurs very rarely as red isotropic grains.

\section{Composition of the Silurian grits}

The sandstones examined included 8 specimens from the Wenlock Denbigh Grits and 30 from the Upper Llandovery Aberystwyth Grits and their equivalents (Tables 1 and 2).

Quartz. The amount of quartz in the Upper Llandovery varies from 24 percent to 84 percent of the whole-rock composition, and in the Denbigh Grits from 33 to 66 percent. Similarly, the ratio of polycrystalline to simple quartz grains is also highly variable in the Upper Llandovery, whereas in the Denbigh Grits polycrystalline quartz is consistently commoner than simple quartz. Grains of the latter are usually very clear, being only scattered or trailed with indeterminable dusts and vacuoles. Polycrystalline quartz grains sometimes develop irregular patches of chlorite along their sutures. Crystalline inclusions (zircon, apatite, biotite, etc.) are also present. Green, pleochroic vermicular "penninite" inclusions sometimes occur (Pl. 2, Fig. 2) (cf. WALLIS, 1927, pl. LVIII). A minority of grains show distinct strain shadows, and include stretched metamorphic quartz.

Rounded quartz grains, even in the fine fractions, are not uncommon. They were probably derived from older sediments, becoming mixed with angular grains which largely escaped significant abrasion (OKADA, 1966). Specimens W 102A and $B$, representing a shelf facies, contain many rounded grains (average roundness 0.50-0.56 on PoweR's scale (1953), for various size grades). Polycyclic derivation rather than beach action seems suggested because the last process is insufficient to account for the marked degree of rounding observed (cf. KUENEN, 1960). This is supported by the presence of fine-grained quartz-arenite consisting wholly of well-rounded clear quartz grains.

Feldspars. The amount of feldspar is very variable, ranging from almost nil in the shelf-facies sandstones to 19 percent in the turbidite-facies of the Aberystwyth Grits. Alkali-feldspars are always commoner than plagioclase. Among the former orthoclase predominates, myrmekite is fairly common, and perthite is not uncommon. Microcline has not been detected in either the Aberystwyth or Denbigh Grits. CUMmins (1957) considered that the complete absence of microcline from the Denbigh Grits is significant. The plagioclase is albite to oligoclase, and shows albite, albite-carlsbad and pericline twinning. There is no difference in feldspar-composition from the Upper Llandovery to the Denbigh Grits. Some of the grains are fairly fresh; others are largely replaced by calcite or scattered with aggregates of minute sericite and kaolin-like minerals.

Rock fragments. Rock fragments seen in thin sections of the Denbigh Grits were: slate, fine-grained quartz-arenite and wacke, chert, granite, granophyre, rhyolitic and porphyritic rocks, andesite, microdiorite, basaltic or spilitic rock, doleritic rock, serpentine, schist and phyllite (cf. Cummins, 1957). Except for the absence of serpentine and the presence of acid to intermediate tuff, the same 
assemblage occurred in the Upper Llandovery rocks.

As a whole the Silurian grits differ from the Cambrian in containing acid to basic volcanic debris and various sedimentary rocks. The Cambrian is characterized by detritus from acid plutonic and volcanic rocks.

Argillaceous matrix. Most of the grits are cemented by argillaceous matter comprising chlorite, sericite and secondary quartz. The composition of the chlorite lies in the field of either thuringite or pseudothuringite-ripidolite (HEY, 1954; Fig. 2). No difference of chlorite composition is thus recognizable between the Silurian and Cambrian, despite their marked contrast in major detritals.

Accessory heavy minerals. Non-opaques, in order of decreasing abundance, are: zircon, tourmaline, garnet, rutile, monazite, augite, spinel. Opaque minerals are pyrite, ilmenite or leucoxene, magnetite and rarely hematite, in that order of abundance (Table 2).

The Silurian heavy mineral association is almost identical with that of the Cambrian, except that epidote and anatase are characteristically Cambrian. Within the Silurian, spinel and augite have been recorded only from the Denbigh Grits. These, in turn, contain more fragments of basic rock than the Upper Llandovery.

Zircon usually reaches 70 percent or more of the non-opaque suite. Euhedral zircon, including colourless to pale pink and yellowish varieties, is nearly twice as abundant as rounded. Purple zircon, usually well rounded though uncommon, is persistent in all the samples examined. A few outgrowths were noted.

Tourmaline shows three pleochroic varieties, known also in the Cambrian (p. 265). Commonest is that with $\mathrm{O}=$ deep reddish brown to deep brown (black in thick grains) $>\mathrm{E}=$ pale brownish yellow. The other two are less common: $\mathrm{O}=$ deep brownish green $>\mathrm{E}=$ almost colourless to pale brownish yellow, and $\mathrm{O}=$ deep green or bluish green $>\mathrm{E}=$ almost colourless to pale green. Most of the grains are euhedral to subhedral, terminated by rhombohedra or basal partings. Colour banding (as in the Cambrian: p. 265), is also rather common among the prismatic grains. Overgrowths are occasionally detected. Opaque inclusions are quite common. Reworked rounded grains of tourmaline are frequently encountered.

Garnet occurs as irregular conchoidally fractured grains. The pinkish variety is by far the commonest. Slightly abraded dodecahedra are also found.

Rutile grains (rounded) were seen in many samples, but never commonly.

Augite, spinel and monazite occur as traces. Authigenic pyrite mostly forms spheres. Less often, it occurs as clusters of globules, stellate clusters of radial spears, and cubes.

\section{Variation of heavy minerals with grain-size}

In order to clarify the effects of current sorting on heavy minerals in the graded turbidite beds, the covariation between heavy mineral frequency and grain-size has been investigated in several pairs of samples spanning the graded interval. Unfortunately the highly indurated nature of the specimens precluded strictly quatitative methods. 




Fig. 3a.

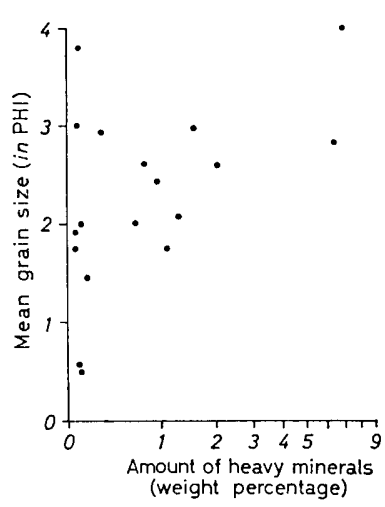

Fig. 3b.

Fig. 3a. Vertical variation of heavy mineral amounts within single beds.

Note an upward increase in the amounts. $W$ 26, 27, 31: Cambrian W 1, 34, 77: Silurian

Fig. 3b. Relation between heavy mineral amount and grain-size. $N=18 ; r=+0.54$, significant at 0.05 level; $y=0.39 x+1.79$

The bulk-amounts of heavy residue tend to increase with decreasing grainsize (Fig. 3). However, the finer the sandstone the more the chlorite residues tend to be concentrated (Table 2). This is especially the case in the Cambrian.

Vertical variation in relative abundance of the common non-opaque minerals through one fining-upwards bed (samples W 31,70,1 and 34) reveals an upwards increase in zircon. Another, however (W 27, and 77), shows an inverse relationship. Variation in tourmaline and garnet is independent of grain-size (Table 2).

It thus seems that selective sorting of heavy grains (reported by STANLEY (1963) from the Annot Sandstone flysch in the French Maritime Alps) is not always important during turbidite accumulation. This contrasts with fluviatile conditions (SUNDBORG, 1956; AlleN, 1948; and others).

\section{Sandstone patterns}

Modal composition of the sandstones and its variation have been described above and previously (OKADA, 1966). Variation in rock composition will now be treated.

Method of classification. Because simplicity, practicality and objectivity are desirable, a descriptive classification is adopted here.

The author considers that GILBERT's classification (1954) as modified by DoTT (1964) is the most satisfactory one. This is because (1) the clay matrix, which is highly significant (whatever its origin may be), is almost as measurable as the quartz, feldspar and rock fragments; (2) the general ratio quartz: feldspars : rock fragments is not always constant among varying matrix percentages (Fig. 4; 


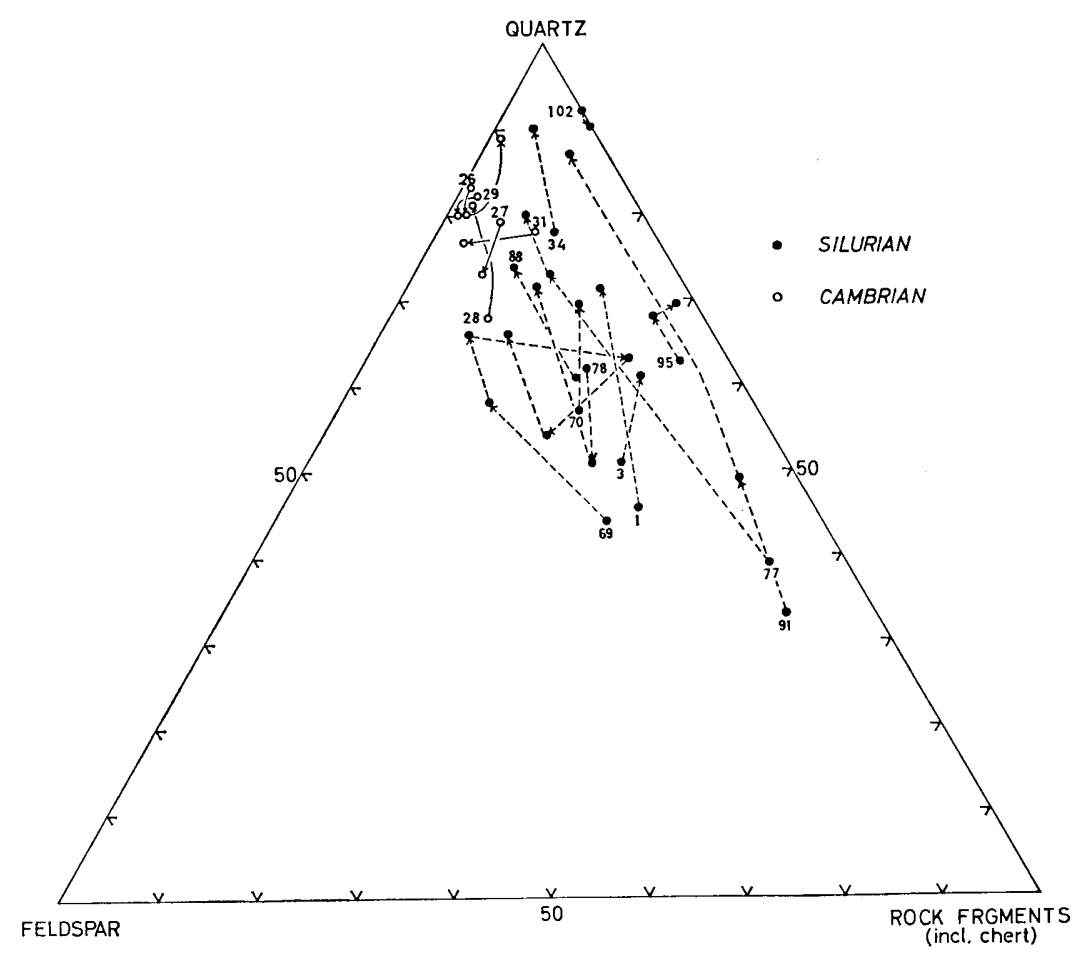

Fig. 4. Relation between Quartz: Feldspar: Rock fragments ratio of sandstones and their position in the graded beds. An arrow indicates the upward direction in the beds; the figure represents the main sample number of a suite of samples. The diagram implies that $Q: F: R$ is not constant as regards clay matrix content.

cf. KLEIN (1963) who pointed out its relative constancy despite variable matrix percentages); (3) the terms "greywacke" and "arkose" are still ambiguous (OKADA, 1966).

The classification adopted is presented on two ternary diagrams (Fig.5). One shows non-muddy or clean-sandstone or arenite, the other muddy sandstone or wacke. For the dividing line between arenite and wacke, 15 percent of muddy matrix is taken, mainly for the reason that 'arenite' then satisfactorily covers the basal parts of the graded sandstones (OKADA, 1966). Quartz, feldspars and rock fragments (including chert) are used as end-members in each triangular diagram. Generalization of this method of sandstone classification will be attempted in another paper.

Sandstones from the marginal facies and the bases of the graded beds fall under the arenites. The Cambrian rocks belong to the feldspathic arenites; the Silurian to the lithic arenites. One specimen from the Aberystwyth Grits and three from the Upper Llandovery shelf facies are quartz arenites. All the specimens from the upper parts of graded beds, on the other hand, and a few samples from the basal parts, are wackes. Nearly all the Cambrian specimens are feldspathic wacke, and the Silurian ones mostly lithic wacke. Only one Cambrian and 

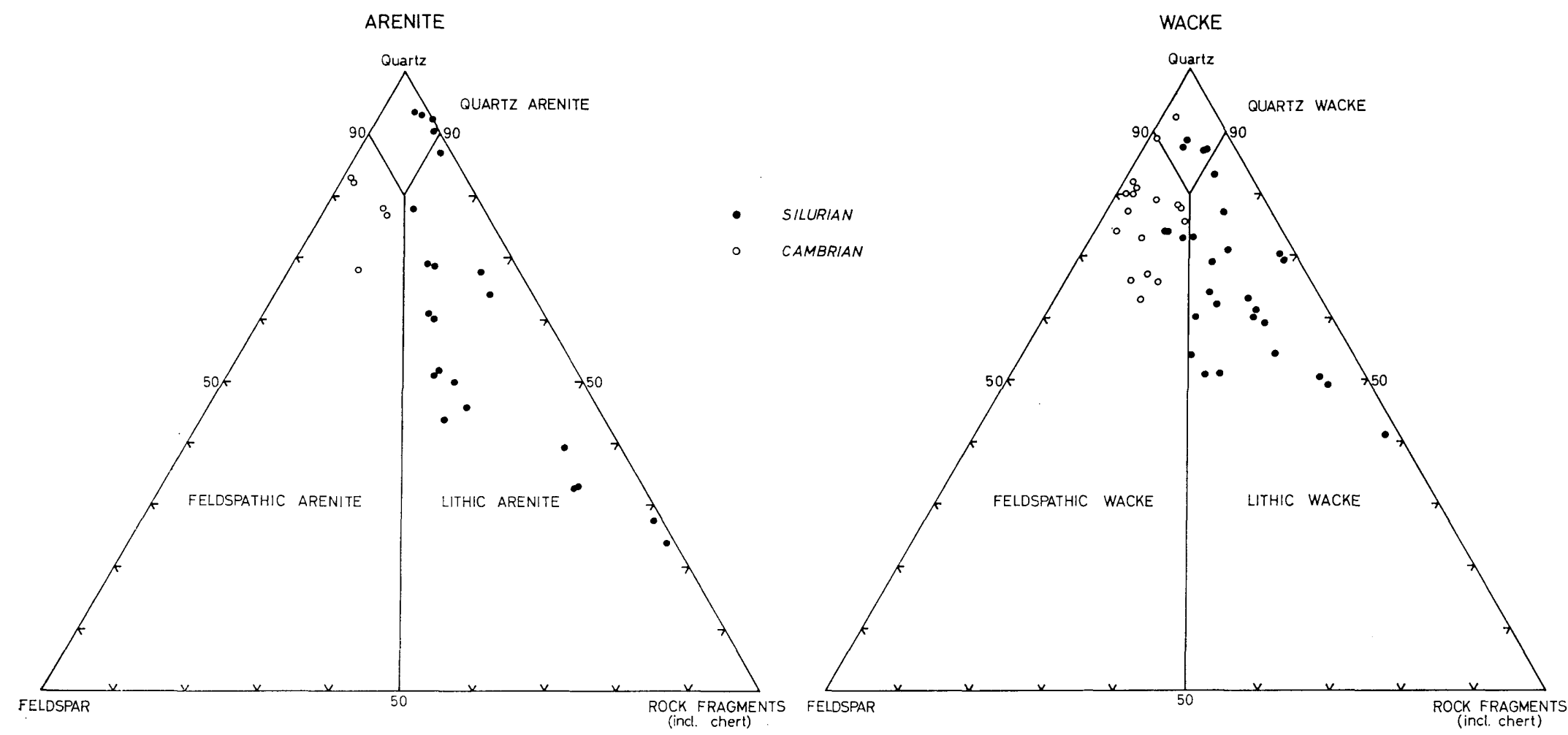

Fig. 5. Sandstone classification adapted from GiLbeRt (1954) and DotT (1964). 
four Silurian samples are quartz wackes.

\section{Cementation of the sandstones}

Among the cementing minerals, chloritic and sericitic clay minerals are volumetrically most important in both Cambrian and Silurian. Calcite and silica cements play minor roles in most cases, though occasionally important.

Clay cementation. In wackes the detrital grains 'float' in the clay matrix without direct grain-to-grain contacts. In arenites most of the detrital grains show sutured or concavo-convex contacts, and some tangential and straight contacts. To understand the relationship beween grain-contacts and clay cementation, mainly arenites have been examined.

Quartz v. quartz: Long concavo-convex and sutured or microstylolitic contacts are common. Examples of the first are commonly sharp and linear, usually showing narrow zones of quartz "crush" (Pl.2, Fig. 3). Minute laths or fibres of chlorite or sericite develop poorly and discontinuously along the contacts. Stylolite contacts show fibrous clay minerals along the characteristic sutures, the quartz 'columns' being sometimes capped by opaque carbonaceous material.

Quartz v. feldspar: Concavo-convex contacts are commonest, with the feldspar usually convex to the quartz. A crush zone is occasionally recognisable, as in quartz-to-quartz contacts. Stylolitic contacts are not uncommon (Pl. 2, Fig. 4). Authigenic clay is insignificant in many cases. Feldspars thinly coated with secondary clay maintain sharp contacts against their neighbours, whether these are quartzes or feldspars (Pl. 2, Fig. 6).

Quartz $v$. rock fragments: As a general rule, the argillaceous fragments are deformed more or less plastically against the quartzes (PI. 2, Fig. 5). Strongly deformed shale fragments often play the role of a matrix (Pl.2, Fig. 5), i.e. a matrix of secondary origin. In other samples no such introduction of clay to the matrix is recognizable.

Contacts between grains of unstable materials are scarce in many of the sandstones. The sole exception is specimen $\mathrm{W}$ 87, which shows rounded grains of rhyolitic and andesitic rocks mostly in tangential contact and coated by thin skins of clay (Pl. 2, Fig. 8). Spaces between the grains are largely filled with secondary quartz (below, p. 273), supplemented by a little chloritic clay. The latter occasionally preserves an original tuff or pumice texture.

Alteration of detrital grains. The quartz grains are often corroded peripherally by pressure-solution. This results in the development of some secondary clay, chlorite or sericite. The feldspars show various degrees of replacement by kaolinite and/or mica (especially sericite) and calcite. Volcanic rock fragments are more or less altered to chloritic minerals. Sometimes the almost completely altered rock-fragments retain their original outlines, being obviously true pseudomorphs (Pl. 2, Fig. 7) rather than a matrix.

To summarize: though secondary clay minerals (resulting from diagenesis of detrital grains) contribute to the matrix (as argued by Cummins, 1962), they are volumetrically insignificant, 
Calcite cementation. Calcite occurs as a replacement mainly of feldspar grains (and occasionally others) rather than as a cement. The replacement seems to post-date both chloritization and silicification, because chlorite aggregates and secondary quartz are often 'trapped' by the calcite, and silica veinlets are partly replaced.

Only a few Upper Llandovery samples, all collected from the basal parts of graded beds, show complete cementation by calcite. The cementation seems to be later than the secondary overgrowths on the quartz grains, because the latter contain no 'trapped' calcite and are, indeed, corroded at the edges by calcite.

Silica cementation. The shelf sandstones (e.g. W 84, 87 and 102A and B, all Upper Llandovery) are characteristically cemented by quartz (Pl. 2, Figs. 8, 9). All except W 87 (Pl. 2, Fig. 8) are quartz-arenites. Cementation is due mainly to secondary quartz-overgrowths. These, developed on clean grain surfaces, are optically continuous with the nucleus. The lithic arenite W 87 also shows voidfilling largely by quartz. This may have been derived from dissolved volcanic silica and/or quartz overgrowths.

\section{Conclusions}

Compositional differences. The Welsh Cambrian and Silurian sandstones clearly differ in general composition.

Sources. The Cambrian sandstones characteristically contain granite, gneiss and acid volcanic and quartz-sandstone debris. This association closely resembles that of the underlying Precambrian, as already pointed out (Woodland, 1938, 1939, 1946; BlaCK, 1957; BASSETt and WALTON, 1960; etc.).

The Silurian Upper Llandovery sandstones contain detritus from rhyolites, porphyries, and intermediate tuffs (some glassy). More basic clasts (e.g. of trachytic and doleritic rocks, basalt, serpentine) characterize the Wenlock sandstones (Denbigh Grits).

Sources of the soda-rhyolites and vitric tuffs in the Upper Llandovery were probably Ordovician. Vitric and pumiceous tuffs are characteristic of the Snowdon volcanics in North Wales (H. Williams, 1927, pp. 372-373, 379-380; D. WILLIAMS, 1930, pp. 205-209), but the Upper Llandovery palaeocurrent structures show transport from the south-west or south-south-west (WOOD and SMITH, 1958). A southwestern source could have included the Precambrian Pebidian volcanics of Pembrokeshire, which are mainly of rhyolites and andesitic tuffs (Thomas and Jones, 1912; T. G. Williams, 1934).

No evidence of Cambrian volcanicity is known. The presence of microdiorite and granitic fragments (and the absence of microcline) suggests Precambrian sources, probably related to the Dimetian of Pembrokeshire (THOMAs and Jones, 1912; T. G. Williams, 1934). Neither Cambrian nor Ordovician plutonics are known in South Wales, and microcline is absent from the Dimetian (THomas and JoNES, 1912, p. 387) though known in other Precambrian granites (Cummins, 1957, p. 442).

Remarkably well-rounded sand grains in both arenites and wackes suggest 
multicyclic origins from older sediments (pp. 263, 267; cf. OKADA, 1966).

Quartz-arenite at Marloes Bay apparently reflects a local source. This was probably Lower Cambrian quartz grit, like that in the Caerfai Beds of Pembrokeshire (T. G. Williams, 1934, p. 44). Likewise, the quartz-arenite $4 \mathrm{~km}$. north of Builth Wells (Breckonshire) may have been derived from Lower Cambrian polycyclic quartz-sands. A lithic arenite south of Johnston (Pembrokeshire) closely resembles rocks of the Pebidian Benton Series. These characteristically contain spherulitic rhyolite and felsite (PrINGLE and GEorge, 1948, p. 14).

Precambrian sources for the Denbigh Grits, postulated by Cummins (1957), are confirmed by the present study.

Classification of the sandstones. The types of sandstone studied may reasonably be classified as arenites and wackes (p. 271). All those from these shelf facies, and many from the basal parts of graded beds, are arenites: feldspathic arenites in the Cambrian, lithic to quartz-arenites in the Silurian. On the other hand, all the fine-grained sandstones, together with those from the upper parts of the graded beds, are wackes: feldspathic wackes in the Cambrian and lithic wackes (accompanied by feldspathic and quartz wackes) in the Silurian. A descriptive classification of this kind is quite simply applicable to the sandstones of any tectotope.

Cementaton. Clay cements in the sandstones are characteristically chlorite and sericite in both Cambrian and Silurian, chlorite being highly important in the Cambrian. No significant difference in chlorite composition is detectable between Cambrian and Silurian, despite the marked contrast in major detrital components. Nor are there vertical differences in chlorite composition within single graded beds. The chlorite in question is thuringite or pseudothuringite-ripidolite, following HEY (1954). The arenites (even the volcanic ones), which seem to have been originally deficient in clay, still retain a little clay. The originally precipitated mud in the wackes seems to be an important source of their matrices.

Calcite (and occasionally dolomite) cementation may have been completed after both chloritization of the matrix and void-filling with silica. Microstylolitic structures are more marked in the Silurian than in the Cambrian. This supports the contention of LERBEKMo and PlatT (1962) that solution of silica is promoted by the presence of carbon and iron compounds.

\section{Acknowledgements}

The present work was undertaken in the Sedimentology Research Laboratory, University of Reading, Great Britain, during the tenure of a British Council award for $1964 / 65$.

Deep appreciation and thanks are extended to Professor Percival ALLEN for his constant encouragement during the investigation and for his critical reading of the manuscript. The writer is also indebted to Alec J. SMITH for critical reading of the manuscript. Thanks for field work are due to John R. L. Allen, Alec J. Smith, D. A. Bassett, W. A. Cummins, Aran LeEs and John E. Thomas. The writer benefited from personal discussions with John R. L. Allen, E. Kendal Walton, Alec J. Smith, W. A. Cummins, G. Kelling, Harold G. Reading and 
D. T. HOPKINS. Mr. E. J. RAYNOR kindly assisted with an X-ray diffraction analysis, and Mrs. D. M. Powell helped in many ways. Appreciation is due to the members of the Sedimentology Research Laboratory generally, for their encouragement and assistance. Particular gratitude is expressed to Professor T. MATsumoto for his constant encouragement throughout the present study and to Professor H. SHIRozu for his valuable discussions on the chlorite problem.

\section{References}

Allen, P. (1948) : Wealden petrology: the Top Ashdown Pebble Bed and the Top Ashdown Sandstone. Quart. J. Geol. Soc. London, 104, 257-321.

Bassett, D. A. and Walton, E. K. (1960) : The Hell's Mouth Grits: Cambrian greywackes in St. Tudwal's Peninsula, North Wales. Quart. J. Geol. Soc. London, 116, 85-109.

BLACK, M. (1960): Sedimentation in relation to the Caledonian movements in Britain. Int. Geol. Cong., Rpt. of the 20th Session. Mexico 1956. Section V. Relaciones entre la tectonica y la sedimentacion, 139-152.

Bouma, A. H. (1962): Sedimentology of some flysch deposits. Elsevier, Amsterdam, 1-168.

Cummins, W. A. (1957): The Denbigh Grits; Wenlock greywackes in Wales. Geol. Mag., 94, 133-451.

(1962): The greywacke problem. L'pool Manch. Geol. J., 3, 51-72.

DÉvERIN, L. (1934): Sur la tourmaline authigène dans les roches sédimentaires. Schweiz. Min. Petr. Mitt., 14, 528-529.

Dотт, R. H., Jr. (1964) : Wacke, graywacke and matrix-what approach to immature sandstone classification? J. Sediment. Petrol., 34, 625-632.

Gilbert, C. M. (1954) : Sedimentary rocks. In: H. Williams, F. J. Turner and C. M. Gilbert, Petrography, W. H. Freeman, San Francisco, 251-384.

HeY, M. H. (1954) : A new review of the chlorites. Min. Mag., 30, 277-292.

KLEIN, G. deVries (1963): Analysis and review of sandstone classifications in the North American geological literature, 1940-1960. Geol. Soc. Am. Bull., 74, 555576.

Krynine, P. D. (1946) : The tourmaline group in sediments. J. Geol., 54, 65-87.

Kuenen, Ph. H. (1960) : Experimental abrasion of sand grains. Int. Geol. Cong., Rpt. of the 21st Session, Copenhagen, 10, 50-53.

Lerbekmo, J. F. and Platt, R. L. (1962) : Promotion of pressure-solution of silica in sandstones. J. Sediment. Petrol., 32, 514-519.

Matley, C. A. and Wilson, T. S. (1947): The Harlech Dome, north of the Barmouth estuary. Quart. J. Geol. Soc. London, 102, 1-41.

OKadA, H. (1960) : Sandstones of the Cretaceous Mifune Group, Kyushu, Japan. Mem. Fac. Sci., Kyushu Univ., Ser. D, 10, 1-40.

__ (1966): Non-greywacke "turbidite" sandstones in the Welsh geosyncline. Sedimentology, 7, 211-232.

Powers, M. C. (1953): A new roundness scale for sedimentary particles. J. Sediment. Petrol., 23, 117-119.

Pringle, J. and George, T. N. (1948) : British regional geology. South Wales. H. M. S. O., London, 1-100.

Stanley, D. J. (1963) : Vertical petrographic variability in Annot Sandstone turbidites: some preliminary observations and generalizations. J. Sediment. Petrol., 33, 783-788.

Sundborg, A. (1956) : The River Klarälven: a study of fluvial processes. Geograf. Ann., 38, 127-316.

Thomas, H. H. and Jones, O. T. (1912) : The Pre-Cambrian and Cambrian rocks of 
Brawdy, Haycastle and Brimaston. Quart. J. Geol. Soc. London, 68, 374-401.

Waldis, F. S. (1927) : The Old Red Sandstone of the Bristol District. Quart. J. Geol. Soc. London, 83, 760-787.

William, D. (1930): The geology of the county between Nant Peris and Nant Ffrancon. Quart. J. Geol. Soc. London, 86, 191-233.

William, H. (1927) : The geology of Snowdon. Quart. J. Geol. Soc. London, 83, 346431.

Williams, T. G. (1934) : The Pre-Cambrian and Lower Palaeozoic rocks of the eastern end of the St. David's Pre-Cambrian area, Pembrokeshire. Quart. J. Geol. Soc. London, 90, 32-75.

Wood, A. and SMiтh, A. J. (1959): The sedimentation and sedimentary history of the Aberystwyth Grits (Upper Llandoverian). Quart. J. Geol. Soc. London, 114, 163-195.

Woodland, A. W. (1938): Petrological studies in the Harlech Grits Series of Merionethshire. Geol. Mag., 75, 366-382, 440-454, 529-539. (1939): The petrography and petrology of the Lower Cambrian manganese ore of West Merionethshire. Quart. J. Geol. Soc. London, 95, 1-35.

(1946): The petrology of the sediments. Appendix to "The Harlech Dome, north of the Barmouth estuary", by C. A. MATLEY and T. S. Wilson. Quart. J. Geol. Soc. London, 102, 29-34. 


\section{Hakuyu OKADA}

Composition and Cementation of Some Lower Palaeozoic Grits in Wales

Plate 2 


\section{Explanation of Plate 2}

Fig. 1. Occurrence of chlorite fibres as a clay matrix (sp. no. W 27A). Open nicols. Scale in $\mathrm{mm}$.

Fig. 2. Vermicular "penninite" inclusions in quartz (sp. no. W 78B). Open nicols. Scale in $\mathrm{mm}$.

Fig. 3. Crush zone along contact between two quartz grains (sp. no. W 27A). Crossed nicols. Scale in mm.

Fig. 4. Microstylolitic contact between quartz (upper part) and orthoclase (lower part) grains. Crossed nicols. Scale in $\mathrm{mm}$.

Fig. 5. Plastic deformation of shale fragment which plays role of matrix (sp. no. W 78B). Open nicols. Scale in $\mathrm{mm}$.

Fig. 6. Thin coatings of clay around feldspar grains (sp. no. W 12). Pore-filling by quartz-overgrowths at centre of photo. Open nicols. Scale in $\mathrm{mm}$.

Fig. 7. Complete alteration of detrital rock fragment to chloritic minerals. These preserve original outline and therefore cannot be regarded as a matrix. Sp. no. W 30. Open nicols. Scale in $\mathrm{mm}$.

Fig. 8. Clay-deficient lithic arenite (sp. no. W87). Pore-space mostly filled by secondary quartz. Open nicols. Scale in $\mathrm{mm}$.

Fig. 9. Clay-deficient quartz arenite (sp. no. W 102). Void-filling due to quartzovergrowths. Open nicols. Scale in $\mathrm{mm}$. 



H. OKADA: Composition and cementation of Palaeozoic grits in Wales 